\title{
Ultrastructure of vegetative cells and autospores of an aerophytic strain of Vischeria stellata (ChOdat ex Poulton) Pascher (Eustigmatophyceae) from Bulgaria
}

\author{
Georg Gärtner ${ }^{1}$, Maya P. Stoyneva ${ }^{2}$, Blagoy A. Uzunov², Antonia D. Manchevi ${ }^{2}$ \\ \& Elisabeth INGOLIĆ ${ }^{3}$
}

\author{
${ }^{1}$ Institut für Botanik der Universität Innsbruck, Sternwartestrasse 15, A-6020 Innsbruck, Austria; Corresponding \\ authore-mail: georg.gaertner@uibk.ac.at \\ ${ }^{2}$ Department of Botany, Faculty of Biology, Sofia University 'St Kliment Ohridski', 8 bld Dragan Zankov, 1164- \\ Sofia, Bulgaria \\ ${ }^{3}$ Zentrum für Elektronenmikroskopie Graz, Steyergrasse 17, A-8010, Graz, Austria
}

\begin{abstract}
During investigation of the algal flora in the area of the Natural rock phenomenon and protected area Belogradchishki Skali (Bulgaria), an aerophytic strain of Vischeria stellata (CHODAT ex POULTON) PAscher was taken in culture and analyzed by means of light (LM) and transmission electron microscopy (TEM). In the present paper some new data obtained on the architecture of vegetative cells and autospores (e.g. cell wall structure, pyrenoid development and organization) are provided as addition to the knowledge on the ultrastructure of this species.
\end{abstract}

Key words: aerophytic algae, autospores, cell wall, cultures, Eustigmatophyceae, pyrenoid, ultrastructure, Vischeria stellata

\section{Introduction}

The small stramenopilic class Eustigmatophyceae, established by HibBerd \& LeEdale $(1970,1971)$, comprises ten genera with about 18 species grouped in five families of the single order Eustigmatales (HibBerd 1981; ANDERSEN et al. 1998; KRIENITZ et al. 2000; Neustupa \& NĚMCOvÁ 2001; Hegewald et al. 2007). The family Eustigmataceae HIBBERD is represented by two coccoid genera - Eustigmatos Hibberd and Vischeria Pascher (Syn.: Chlorobotrys sensu Chodat ex Poulton, Polyedriella PASCHER), both common in aeroterrestrial habitats (ETTL \& GäRTNER 1995). The last one is known with about 12 taxa, of which only four have been flagged as currently accepted taxonomically (e.g. GUIRY in GUIRY \& GUIRY 2011) according to the information on genus morphology, cytology (incl. ultrastructure), reproduction and ecology (e.g. Pascher, 1939; Hibberd \& Leedale 1972; HibBerd 1981, 1990; SAntos 1990, 1996; SAntos \& LeEDALE 1991; EtTL \& GärTNER 1995; SANTOS et al. 1996). The main diagnostic features for Vischeria, as it is for all eustigmatophyceans, include the chloroplast organization, the presence and the type of pyrenoid and the presence of lamellate vesicles in the cytoplasm or around the pyrenoid(HibBERD \& LeEDALE 1972; HibBERd 1990; SANTOS 1990, 1995, 1996). Therefore, naming the research perspectives in the whole class, SANTOS (1996) stressed the necessity for more detailed studies on the ultrastructure of vegetative cells.

During investigation of the algal flora in the area of the Natural rock phenomenon and protected area Belogradchishki Skali (Bulgaria), a strain of Vischeria stellata (CHODAT ex Poulton) PAscher from aerophytic habitat was taken in culture and analyzed by means of light (LM) and transmission electron microscopy (TEM). The data obtained on some details of the architecture of vegetative cells and autospores (e.g. cell wall structure, pyrenoid development and organization) add a little to the knowledge on the ultrastructure of this species, which in the previous studies (mentioned above) was based mainly on the cytology of vegetative cells and zoospores. 


\section{Material and Methods}

In April and September 2009, after receiving a special permission from the Bulgarian Ministry of Environment and Waters, 158 samples of aerophytic epilithic and endolithic algae (including Cyanoprokaryota) were collected from 12 localities of the Nature rock phenomenon and protected area Belogradchishki Skali, situated in the vicinities of the town Belogradchik (Northwestern Bulgaria). The material from spots and layers visible with naked eye on rock surface and fissures, tree-barks and soil crusts was scraped off from the substratum with sterile knife or needle, and directly transferred into sterile glass tubes containing BBM-agar of BISCHOFF \& BOLD (1963) according to the newly established direct collecting method (DC-method - GÄRTNER et al. 2010). The tubes were immediately closed with aluminium caps and sealed up with Parafilm to avoid further contamination. In the laboratory, the tubes were incubated at room temperature $\left(21^{\circ} \mathrm{C}\right)$ with an irradiance of $\sim 60 \mu \mathrm{mol}$ photons $\mathrm{m}^{-2} \mathrm{~s}^{-1}$ and a light dark regime of 14:10 h. After 6 months incubation, algal material was transferred from the tubes onto agar plates and single cells or groups of cells were isolated by streaking across the agar surface (PRINGSHeim 1946; ETtL \& GäRTNER 1995; Andersen \& KaWACHI 2005; Uzunov 2009). After repeated procedure of cell streaking and continuous incubation, the obtained pure strains were transferred into new agar tubes and maintained as a part of the Algal Collection of the Sofia University (ACUS).

The strain of Vischeria stellata (ACUS84), used in this study, was isolated from the aerophytic material collected from the flattened top surface of a rock with coordinates N 43 35.504+E 22 43.789, situated at $420 \mathrm{~m}$ a.s.1., when the temperature near to the rock surface was $22^{\circ} \mathrm{C}$. First observations of algae and their isolation for axenic cultures were made with a Motic stereomicroscope SFC 11 at a magnification $10 \times$ and $30 \times$. Light microscopic investigations were done by a Motic BA 400 microscope with objectives $10 \times, 20 \times$, $40 \times$ and $100 \times$ (oil immersion) and standard staining by Methylene Blue, Gentian Violet and Iodine solution was applied (ETTL \& GÄRTNER 1995). Photomicrographs were taken with a Moticam 2000 camera attached to the microscope with special adaptors and then processed by the computer software 'Motic Images Plus 2.0'.

For transmission electron microscopy (TEM) algae were fixed in 3\% glutaraldehyde in $0,1 \mathrm{~mol}$ cacodylate buffer $\mathrm{pH}$ 6.8-7.2 for 24 hours and postfixed with $1 \% \mathrm{OsO}_{4}$ in $0.1 \mathrm{~mol}$ cacodylate buffer for several hours. After dehydration in ethanol/acetone and embedding in Spurr's resin (SPURR 1969), ultrathin sections were cut with a diamond knife (Leica UCT microtome) and stained with $1 \%$ aqueous uranyl acetate and lead citrate (REYNOLDS 1963). Micrographs were taken with a Philips 300 transmission electron microscope.

\section{Observations}

In cultures studied, the vegetative cells of Vischeria stellata are oval to globular, but there is always a proportion of young cells with angular, slightly polyhedral shape, $4.8-10 \mu \mathrm{m}$ in diameter (Figs 1-5, 7, 9, 11, 18). By LM, on higher magnifications after staining by Methylene Blue and Gentian Violet, the cell wall is seen as folded, often covered with single, clearly separated (detached) protrusions - humps in the terminology of PASCHER (1939) - Figs 1- 7, 9, 11, 17, 18. Their apices are rounded to slightly tapered, conical (Figs 4-7, 9-11). By means of TEM it is visible that the humps are hollow, generally filled-up with a cytoplasm instead of cell wall material (Figs 6, 10). Rarely, smooth-walled spherical cells appeared among the angular ones.

In LM, the unipartite cell wall (with or without humps) always is visible as one, homogenous structure. However, in TEM, up to seven layers could be enumerated in the walls both of vegetative cells and autosporangia (Fig. 17). The young autospores inside the autosporangium firstly are with smooth cell walls (Fig. 13), while the walls of most of the developed autospores are folded, raised into humps (Figs 15, 17).

The cells and autospores contain one chloroplast, which is cup-shaped, lobed and therefore on some TEM photos, depending on the plane of the cutting for transverse section, it looks like if there are two or three plastids (Figs 17, 18). In ultrastructural aspect, the lack of girdle lamella is obvious and thylakoids are evenly spaced, grouped by three, running through the whole matrix almost till the plastid margins (Figs 7, 8, 17, 18). Each chloroplast contains a single large pyrenoid. In the chloroplasts of young autospores with smooth cell wall, it appears as immersed just beneath the plastid membrane (Figs 13, 14) but afterwards, in well developed, released autospores and in vegetative cells, it is well protruded from the chloroplast, to which it remains attached by a small, narrow connection - stalk (Fig. 9). The pyrenoid has been seen also as polyhedral (mainly pyramidal), laying with its large side on the chloroplast (Figs 4, 5, 8, 15, 16). The developed projecting pyrenoid with polyhedral shape is large enough to fill up to $1 / 3$ of the cell lumen (Figs $3-5,7-9,15,16)$. The matrix of the pyrenoid is not penetrated by thylakoids, but its outer surface is surrounded by extraplastidal flattened lamellate vesicles, one of which lies against each face of the 

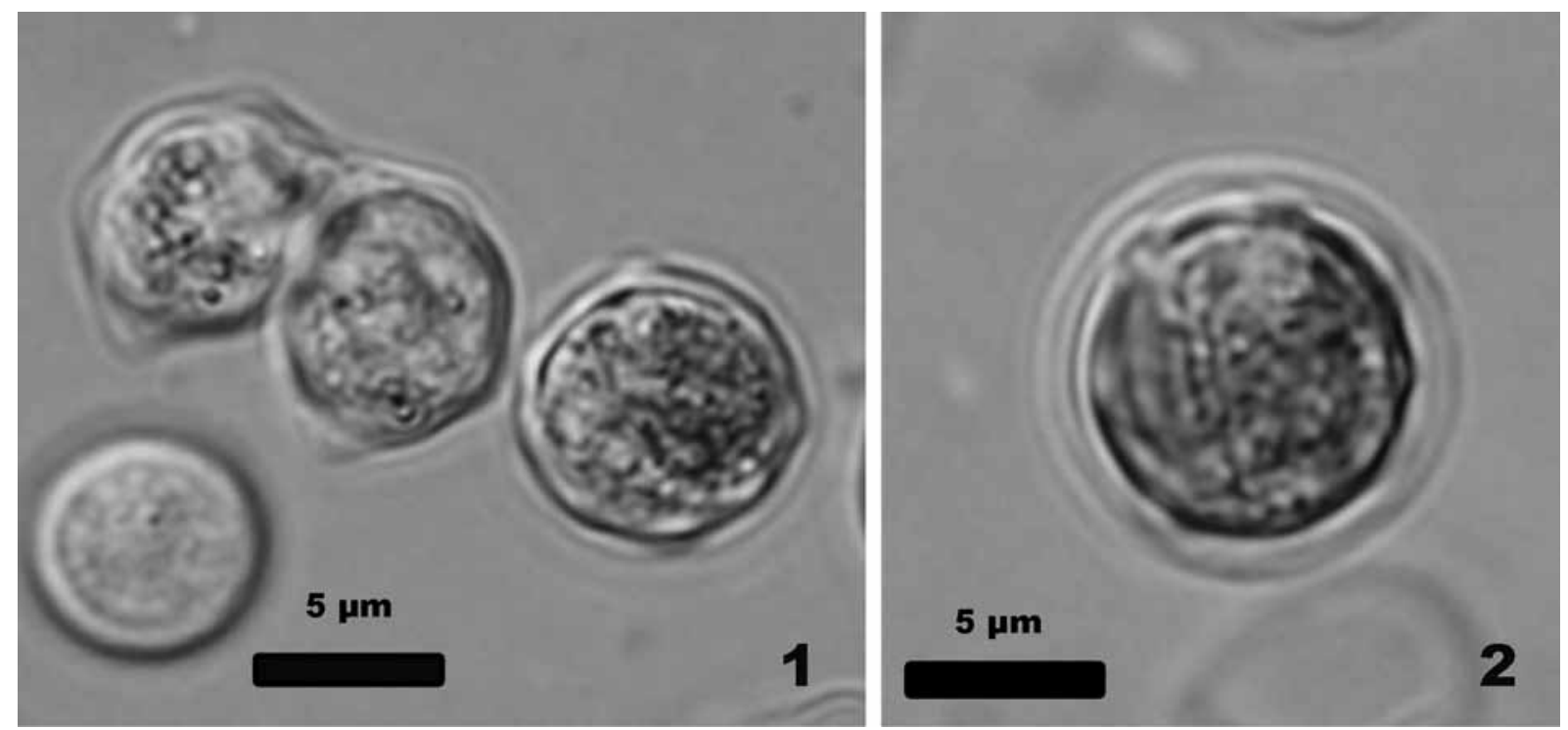

Figs 1-2. Vegetative cells and autospores of Vischeria stellata in LM. Scale bar indicated at each photo.

pyrenoid (Figs 3-5, 7-9, 15, 16). Even the young pyrenoid in autospores is supplied with at least one vesicle (Figs. 13, 14).

Some cells, and the young autospores particularly, are supplied by large droplets, which are seemingly of oil nature (Fig. 13). In addition, most of the cells bear numerous globules (?microbodies, ?vesicles) of unclear structure and chemical content. They are located below the cell wall in vegetative cells and developed autospores (Figs 3-5, 7, 11, 15, 16) but sometimes are situated deeper in the protoplast, reaching the area around the nucleus, which contains a single nucleolus (Fig. 12). In some of the cells, the same globules are densely packed (concentrated) in one larger, common structure (Figs 9, 10).

\section{Discussion}

The cytological and ultrastructural features of the studied aerophytic material are on general conformity with the characteristics described earlier by means of LM (PASCHER 1939) and later by TEM (Hibberd \& LeEdale 1972; HibBerd 1990; SAntos 1996; Neustupa \& NĚMCOVÁ 2001) on soil strains of Vischeria. This statement has to be noted especially for the hollow character of the cell wall hump-like protrusions - a feature outlined by PASCHER (1939) on the basis of LM only (!) and originally depicted in his figures 406, 407 and 408. As far as cell morphology is concerned, the present observations fit to the data provided by HibBerd \& LeEDALE (1972) on the usual presence of both globular and angular cells in the cultures of Vischeria stellata.

The single and unique in its angular shape pyrenoid without penetrating thylakoids also fits to the descriptions provided earlier (HIBBERD \& LEEDALE 1972). Here it is to be underlined that, despite of the fact that this pyrenoid was generally described as protruded, having only a narrow stalk connection with the plastid (op. cit, p. 56, $9^{\text {th }}$ common feature for all Eustigmatophyceae), the same authors wrote that, in the cultures of Vischeria helvetica (Syn.: Polyedriella helvetica), occasional cells are seen in which the region of attachment covers a greater area of the surface of the chloroplast (op. cit., p. 55). The last pyrenoid type was already registered by ANTIA et al. (1975) as typical in the eustigmatophycean species Nannochloris oculata DROOP and Monallantus salina BourRelly, and documented on their schematic drawing (op. cit, Fig. 6b). The same situation appeared on most of our TEM photos (Figs. 4, 6-8, 15, 16), where the pyrenoid is seen with a polyhedral shape, attached to the plastid by its largest side. According to HiBBERD \& LEEDALE (1972, p. 55) the pyrenoid is closely surrounded by the chloroplast envelope and chloroplast ER, which together form a single dense structure in which the individual membranes cannot be normally recognized. On our TEM photos this common membrane is difficult to be seen everywhere, but we believe that it covers the whole pyrenoid. The granular outlook of the immersed 

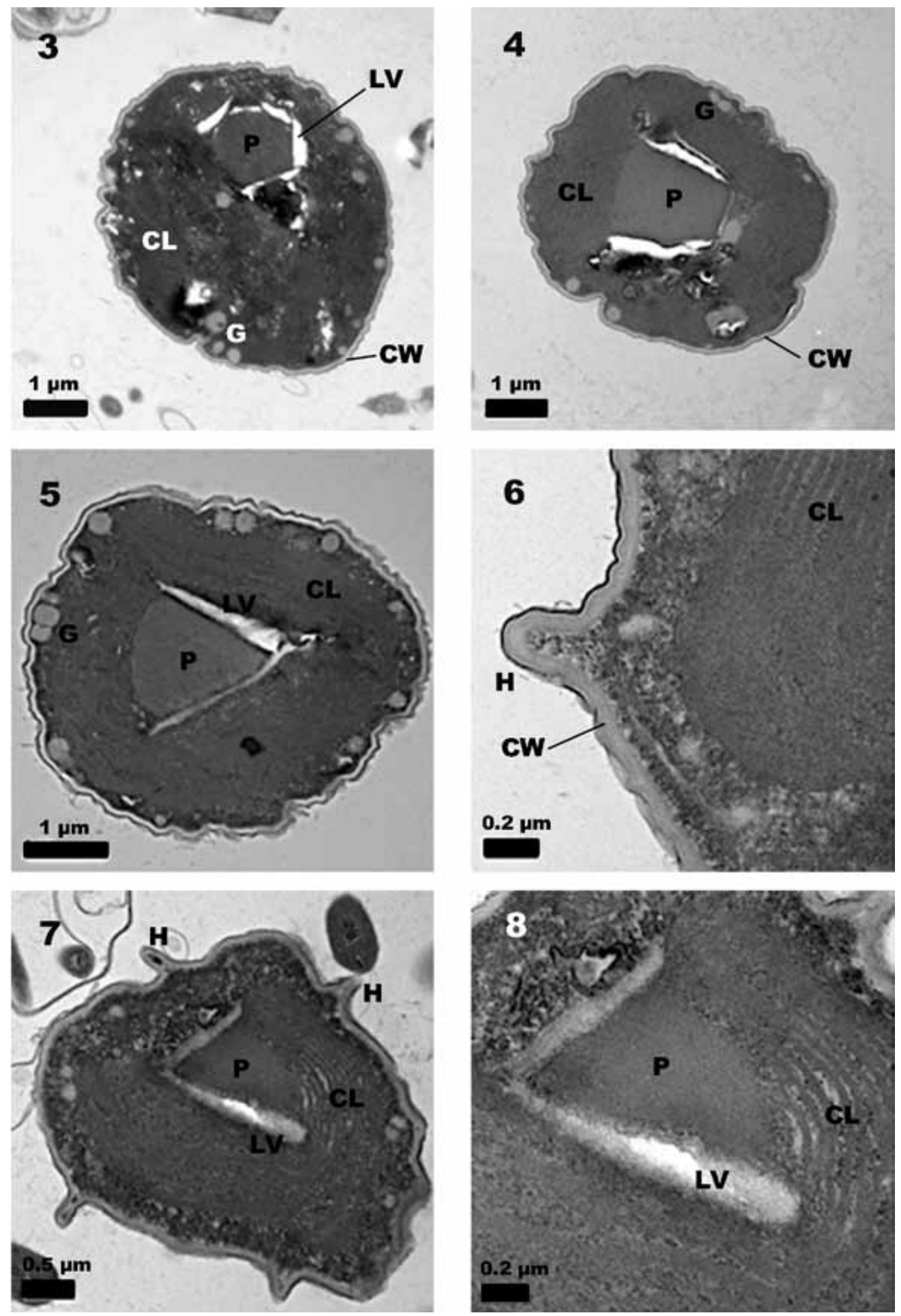

Figs 3-8. Ultrastructure of vegetative cells of Vischeria stellata: (3-5) young cells with slightly folded cell walls (CW) with globules $(\mathrm{G})$ beneath them, chloroplast $(\mathrm{CL})$, large protruded polyhedral pyrenoid $(\mathrm{P})$, surrounded by sheath of lamellate vesicles (LV); (6) detail of the thick cell wall (CW) with singular hump $(\mathrm{H})$, filled-up with cytoplasma; (7-8) cell and its detail with well expressed humps $(\mathrm{H})$ on the cell wall, large protruded pyramidal pyrenoid $(\mathrm{P})$, surrounded by sheath of lamellate vesicles (LV), attached by its large basis to the chloroplast (CL); thylakoids in all the chloroplasts are grouped by three in a lamella; girdle lamella everywhere is lacking. Scale bar indicated at each photo. 

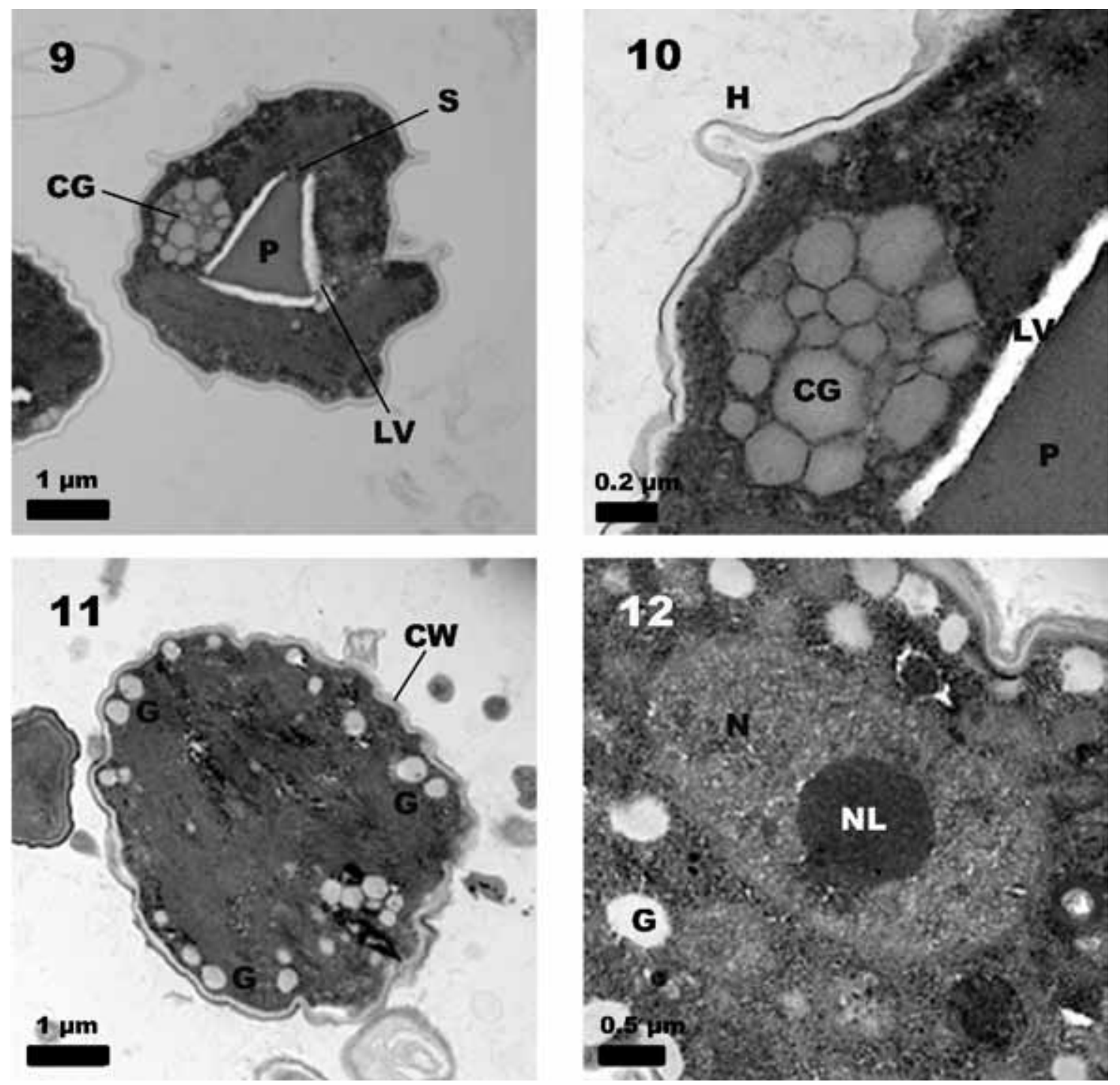

Figs 9-12. Ultrastructure of vegetative cells of Vischeria stellata: (9-10) angular young cell and its detail with concentration of globular bodies (CG) and large protruding pyrenoid (P), attached to the chloroplast by narrow stalk (S) and surrounded by sheath of lamellate vesicles (LV); (11) cell with numerous singular globular bodies (G) under the folded cell wall (CW); (12) detail of a cell with nucleus $(\mathrm{N})$ and nucleolus $(\mathrm{Nl})$ with globules $(\mathrm{G})$ in its vicinity. Scale bar indicated at each photo.

pyrenoids in very young autospores (Figs 13, 14) allows us to suppose that they appear de novo below the chloroplast membrane. They resemble the situation with the settling cells in which the pyrenoid starts to grow from the inner surface of the chloroplast very soon after the zoospore becomes immobile (HIBBERD \& LEEDALE 1972, p. 55).

According to the opinion of HIBBERD \& LeEdale (1972), HibBerd (1990) and Santos (1996) the extraplastidal lamellate vesicles surrounding the pyrenoid contain the storage products the chemical nature of which remains unknown. Only SChNepf et al. (1995/1996, p. 248) discussed the probability that it is a densely packed, crystalline paramylum-like polysaccharide, consisting of $\beta$-1,3-glucan (or another sugar) with helical molecules.

Still unknown, as well, are the nature and the role of the globules (?microbodies, ?vesicles) spread more or less evenly beneath the cell wall. It is possible to suppose that firstly, in young cells, they are concentrated in larger common body (Figs. 9, 10) and only afterwards are transported in the outer parts of the cytoplasm (Figs 3-5, 7, 11, 15, 16). Probably, the structure, mentioned as eigenartige zentrale Ballen (PASCHER 1939) or glänzende Ballen (VISCHER 1945) and later referred as central vacuole surrounded by refractile granules (HiBBerd \& LEEDALE 1972) is related in some way to the concentration of globules, observed by us (Figs 9, 10). In some way, they 

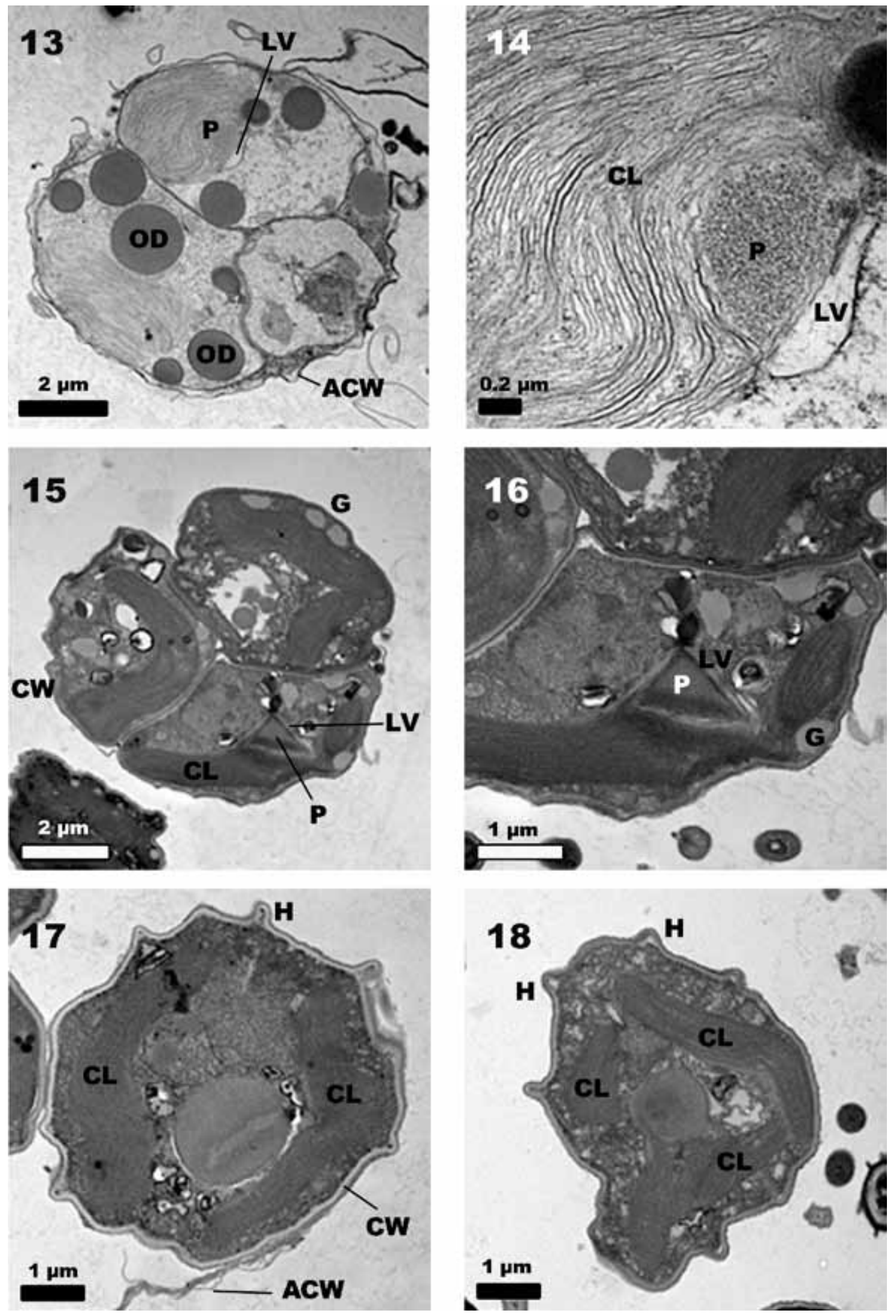
resemble also the smaller spherical dense vesicles with organized contents which are commonly peripheral but can also occupy a more internal position in the zoospores, as they are described and documented by HibBerd \& Leedale (1972, p. 52, their Plates 2B and 3A). However, we did not see any content inside the globules (Figs 3-5, $7,11,12,15,16)$. For the discussion one more description of HibBerd \& LeEDALE (1972, p. 55) on the ultrastructure of the vegetative cells of Vischeria helvetica has to be taken into account: In addition to the lamellate vesicles and a number of osmiophilic globules, each cell contains a large vesicle with globular contents which probably corresponds to a red-pigmented body commonly seen in light microscopy, particularly in older cultures. The same authors mentioned also a third category of vesicle, which is small, dense globule with an intervening electron-transparent space and occurs peripherally (op. cit, p. 52-53). Additionally, they noted the presence of droplets of an electron-dense material without a bounding membrane which are present in small numbers throughout the cells of zoospores (op. cit, p. 53). Obviously, it has to be concluded that still the observations are not enough to make a statement on the relation of the descriptions cited above and the globules found in our material.

The reproduction of Vischeria stellata by zoospores, with their ultrastructural details, was already well studied (HibBerd \& LeEdale 1972; SAntos 1996; SAntos et al. 1996). By contrast, the formation of autosporangia was occasionally reported (PASCHER 1939) and the ultrastructure of autospores was never documented. According to our observations, in culture conditions, Vischeria stellata often produces autosporangia and autospores. We managed to follow their formation from young stages with smooth cell walls and immersed (?semi-immersed) non-angular pyrenoids in chloroplasts till welldeveloped autospores with folded cell walls with hump-like projections and large angular protruding pyrenoids. This is a striking difference from the zoospores, where pyrenoids have not been observed (HibBERD \& LEEDALE 1972; SANTOS 1996). Finding of pyrenoids in autospores seems predictable, but it has to be noted that still in the phycological literature is stated that they occur in vegetative cells only, as it was formulated around 40 years ago (HibBerd \& LeEdale 1972, p. 56).

The observations achieved during this study add a little knowledge on the ultrastructure of vegetative cells and autospores of Vischeria stellata, but also show the necessity for further investigations on this important diagnostic feature.

\section{Acknowledgements}

The present study was carried out in the framework of the projects Aerophytic algae of the rock phenomenon and Nature monument Belogradshishki Skali (N79/15.05.2009), Study of endolithic algae from the rock phenomenon and Nature monument Belogradshishki Skali (N252/1.06.2010) and Studies on the aeroterrestrial algae from the rare class Eustigmatophyceae from the rock phenomenon and Nature monument Belogradshishki Skali (N70/15.04.2011) financed by the Scientific Financial Fund of Sofia University "St Kliment Ohridski".

\section{References}

Andersen, R. A \& Kawachi, M. (2005): Traditional microalgae isolation techniques. - In: R. A. ANDERSEN (ed.): Algal culturing techniques. - pp. 83-100, Elsevier Academic Press, Burlington, San Diego, London.

Andersen, R. A.; Brett, R. W.; Potter, D. \& Sexton, J. P. (1998): Phylogeny of the Eustigmatophyceae based upon 18S rDNA, with emphasis on Nannochloropsis. - Protist 149: 61-74.

Antia, N. J.; Bisalputra, T.; Cheng, J. Y. \& Kalley, J. P. (1975): Pigment and cytological evidence for reclassification of Nannochloris occulata and Monallanthus salina in the Eustigmatophyceae. - J. Phycol. 11: 339-343.

Ettl, H. \& GÄRTNER, G. (1995): Syllabus der Boden-, Luft- und Flechtenalgen. - 721 pp., Gustav

Figs 13-18. Ultrastructure of autospores of Vischeria stellata: (13-14) autosporangium and its detail with a folded common mother cell wall (ACW) and young autospores with smooth cell walls, containing many large oil (?) droplets (OD) and chloroplast with immersed pyrenoid (P) with granular content and one lamellate vesicle (LV) in its sheath; (15-16) autosporangium and its detail with older autospores with folded cell walls $(\mathrm{CW})$, containing chloroplast with protruding pyramidal pyrenoid $(\mathrm{P})$, surrounded by lamellate vesicles (LV) and globules (G) below the cell wall; (17) detail of autosporangium with developed autospore inside its cell wall (ACW) with cell wall bearing well-formed humps (H) and a lobed chloroplast (CL), visible on the section like two chloroplasts; (18) angular newly released autospore with cell wall bearing well-formed humps (H) and a lobed chloroplast (CL), visible on the section like three chloroplasts. Scale bar indicated on each photo. 
Fischer Verlag, Stuttgart, Jena, New York.

Gärtner, G.; Stoyneva, M. P.; Mancheva, A. D. \& Uzunov, B. A. (2010): A new method in collection and cultivation of aerophytic and endolithic algae. - Ber. nat. med. Verein Innsbruck, 96: 27-34.

Guiry, M. D. (Guiry, M. D. \& Guiry, G. M., eds) (2011): AlgaeBase. World-wide electronic publication, National University of Ireland, Galway. http:// www.algaebase.org; searched on 22 May 2011. Algaebase taxon LSID: urn:lsid:algaebase. org:taxname: 86727

Hegewald, E.; PAdisak, J. \& Friedl, T. (2007): Pseudotetraëdriella kamillae: taxonomy and ecology of a new member of the algal class Eustigmatophyceae (Stramenopiles). Hydrobiologia 586: 107-116.

HibBerd, D. J. (1981): Notes on taxonomy and nomenclature on the algal classes Eustigmatophyceae and Tribophyceae (synonym Xanthophyceae). - Bot. J. Linn. Soc. 82: 93-119.

Hibberd, D. J. (1990): Phylum Eustigmatophyta. - In: Margulis, L.; Corliss, J. O.; Melkonian, M. \& Chapman, D. J. (eds): Handbook of Protoctista. - pp. 326-333, Jones and Bartlett, Boston.

Hibberd, D. J. \& Leedale, G. F. (1970): Eustigmatophyceae - a new algal class with unique organization of the motile cell. - Nature 225: 758-760.

Hibberd, D. J. \& Leedale, G. F. (1971): A new algal class - the Eustigmatophyceae. - Taxon 20: 523-525.

HibBerd, D. J. \& Leedale, G. F. (1972): Observations on the cytology and ultrastructure of the new algal class, Eustigmatophyceae. - Ann. Bot. 36: 49-71.

Krienitz, L.; Hepperle, D.; Stich, H.-B. \& Weiler, W. (2000): Nannochloropsis limnetica (Eustigmatophyceae), a new species of picoplankton from freshwater. - Phycologia 39: 219-227.

Neustupa, J. \& NĚMcovÁ, Y. (2001): Morphological and taxonomic study of three terrestrial eustigmatophycean species. - Nova Hedwigia 123: 373-386.

PAscher, A. (1939): Heterokonten. - In: Kolkwitz, R. (ed.): Dr. L. Rabehorst's Kryptogamenflora von Deutschland, Österreich und der Schweiz 11. 1092 pp., Akad. Verlagsges., Leipzig.

Pringsheim, E. G. (1946): Pure Cultures of Algae. - 119 pp., Cambridge University Press, Cambridge.

REYNoldS, E. S. (1963): The use of lead citrate at high $\mathrm{pH}$ as an electron opaque stain in electron microscopy. - J. Cell Biol. 17: 208-212.

Santos, L. M. A. (1996): The Eustigmatophyceae: Actual knowledge and research perspectives. Nova Hedwigia 112: 391-405.
Santos, L. M. A. \& Leedale, G. F. (1991): Vischeria stellata (Eustigmatophyceae): Ultrastructure of the zoospores, with special reference to the flagellar apparatus. - Protoplasma 164: 160167.

Santos, L. M. A.; Melkonian, M. \& Kreimer, G. (1996): A combined reflection confocal laser scanning, electron and fluorescence microscopy analysis of the eyespot in zoospores of Vischeria spp. (Eustigmatales, Eustigmatophyceae). Phycologia 35: 299-307.

Schnepf, E.; Niemann, A. \& Wilhelm, C. (1996): Pseudostaurastrum limneticum, a eustigmatophycean alga with astigmatic zoospores: morphogenesis, fine structure, pigment composition and taxonomy. - Arch. Protistenkd. 146: 237-249.

Spur, A. R. (1969): A low viscosity epoxy resin embedding for electron microscopy. - J. Ultrastruct. Res. 26: 31-43.

Uzunov, B. A. (2009): Aeroterrestrial algae from Pirin Mountain (Bulgaria). 114 pp., Ph D Thesis, Fac. Biol. University Innsbruck.

(C) Czech Phycological Society (2012)

Received June 6, 2011

Accepted October 13, 2011 